\title{
Comparative in vitro Antidiabetic and Immunomodulatory Evaluation of Standardized Five Select Medicinal Herbs and Spectral Analysis of Boerhavia erecta L. (Nyctaginaceae)
}

\author{
Suresh Kumar Karri, Angappan Sheela*
}

\section{Suresh Kumar Karri, \\ Angappan Sheela* \\ Department of Chemistry, School of \\ Advanced Sciences, VIT University, Vel- \\ lore 632014, Tamil Nadu, INDIA.}

\section{Correspondence}

Dr. A. Sheela,

Associate Professor, Department of Chemistry, School of Advanced Sciences, VIT University, Vellore - 632014 Tamilnadu, INDIA.

Phone no: $91+9442712764$

E-mail: asheela@vit.ac.in

\section{History}

- Submission Date: 05-02-17;

- Review completed: 07-03-17;

- Accepted Date: 13-03-17.

\section{DOI : 10.5530/pj.2017.3.57}

Article Available online

http://www.phcogj.com/v9/i3

\section{Copyright}

(C) 2017 Phcog.Net. This is an openaccess article distributed under the terms of the Creative Commons Attribution 4.0 International license.

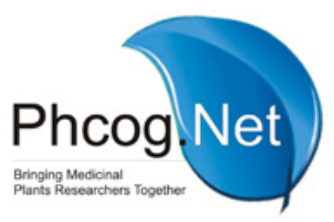

\begin{abstract}
Aim: The present work compares standardized hydro-alcoholic extracts of root and stem parts of Boerhavia erecta L. (Nyctaginaceae), leaves of Plumeria acuminate R. Br. (Apocyanaceae), rhizomes of Alpinia galanga Sw. (Zingiberaceae), whole plant of Picrorhiza kurroa Royle ex Benth. (Plantaginaceae), fruits of Trapa natans L. (Trapaceae) for their in vitro antidiabetic and immunomodulatory activities, commonly used by the Trichigadi tribes (Kotas) of south India for various inflammatory disorders. Materials and Methods: Antidiabetic activity of these herbal extracts was assessed through inhibition of glycosylation of hemoglobin and glucose uptake in yeast cells methods at 50, 100 and $200 \mu \mathrm{g} / \mathrm{mL}$ for $72 \mathrm{~h}$. Their respective immunomodulatory activities were evaluated through preservation of heat and hypotonic induced hemolysis, nitroblue terazolium assay and by inhibition of TNF- $\alpha$ and nitric oxide (NO) production in RAW cell lines. Results: $B$. erecta has shown least cytotoxicity (CTC ${ }_{50}$ $15.7 \%)$ and highest \% inhibition of TNF- $\alpha(58.1)$ and NO (45.6), statistically significant $(p<0.01)$ to that of normal control. Also, B. erecta (BE), and P. acuminate (PA) exhibited relatively better IC50 values for TNF- $\alpha$ and NO at a concentration less than their respective $\mathrm{CTC}_{50}$ values. Conclusions: Spectral analysis of chloroform fraction of $\mathrm{BE}$ hydro-alcoholic extract established the presence of biologically active molecule in it. Root and stem parts of BE extract not only proved to be safe but also demonstrated relatively better efficacy than other established medicinal herbs in selected immune models, may be due to flavonoids or phenolic groups. Further in vivo studies on active molecule of BE towards antidiabetic and immunomodulatory activity are warranted.
\end{abstract}

Key words: Phytochemical, Pharmacognostic, Quality control, NBT assay, Cytotoxicity, TNF $-\alpha$, Nitric oxide.

\section{INTRODUCTION}

Herbal medicine was viewed less enthusiastically for many years inspite of its best therapeutic effect. ${ }^{1}$ Herbal products were discarded from conventional medical use for some time, not because they were ineffective but were considered as economically nonprofitable by the newer synthetic drug manufacturers. ${ }^{2}$ Further, very few reports are available on adverse effects with herbals. With few contentions, it can be mentioned that herbals could be safe alternatives to pharmaceuticals because of long term adverse effects of the latter class. ${ }^{3-6}$ Reports from previous studies indicate that anti-inflammatory drugs exerting their action through immune mediated pathway could address disease conditions such as rheumatoid arthritis (RA), type 1 diabetes (T1D) or other autoimmune disorders. $^{7-10}$ As a part of our hypothesis in establishing a relationship between RA and T1D, the two most common autoimmune disorders; and addressing them through herbal route, our current work was the first step towards exploring for a relatively better herbal extract (s) that exhibits good immunomodulatory and antidiabetic activities together. So, different parts of a few selected herbs, commonly used by the Trichigadi tribes (Kotas) of south India for vari- ous inflammatory disorders, were explored for their antidiabetic and immunomodulatory activities.

Different parts of five herbs were screened, standardized, tested for their quality control aspects, and evaluated for their relative antidiabetic and immunomodulatory activities hitherto unreported, so far. Recent studies on Boerhavia erecta L. (Nyctaginaceae) revealed that its leaves have therapeutic properties and hence could be used as source for nutraceuticals. ${ }^{[11]}$ However, the roots and stems of $B$. diffusa, a close family species of $B$. erecta, show potent Antidiabetic ${ }^{12}$ and immunomodulatory ${ }^{13}$ activities. As no work per se has been reported till date on the responsible active compound of $B$. erecta, the folk medicine, root and stem parts were selected for the present study. Plumeria acuminate R. Br. (Apocyanaceae): The leaves, bark, flower and oil of Plumeria acuminata are used in many countries. ${ }^{14,15}$ However, its immunomodulatory properties were not tested. Alpinia galanga Sw. (Zingiberaceae): Anti-inflammatory ${ }^{16}$ Antidiabetic $^{17}$ and immunomodulatory ${ }^{18}$ properties of Alpinia galanga were earlier reported in various animal models with conflicting results. However, in vitro studies per se were not performed on the hydro 
alcoholic extracts of its rhizome, the major tribal medicine in south India. Picrorhiza kurroa Royle ex Benth. (Plantaginaceae): It has been well established for its hepatoprotective, anticholestatic, antioxidant, and immune-modulating activity. ${ }^{19,20}$ Very little information is available on its antidiabetic and immunomodulatory activities by in vitro methods. Trapanatans L. (Trapaceae): Though anti-inflammatory and antidiabetic activities ${ }^{21}$ were well presented on the fruit extracts of Trapa natans, in vitro studies on its hydro-alcoholic extracts have not been explored earlier. In view of the existing literature on these five herbs and their respective parts, an attempt has been made to explore for the best herb (s) that exhibits relatively better antidiabetic and immunomodulatory activities and possess good efficacy to act as an alternate to pharmaceutical drug molecules. For the first time, we have explored the specific parts of these selected herbs used by the local tribals as folk medicine and presented their relative antidiabetic and immunomodulatory activities by in vitro methods for the first time. Also, presence of biologically active molecule of $\mathrm{BE}$ has been demonstrated for the first time through spectral analysis. As a part of our hypothesis in establishing a correlation between Rheumatoid arthritis and Type 1 Diabetes (two autoimmune disorders) and possible treatment options with herbal drugs, current manuscript presents preliminary evidence of five selected standardized herbs for such pharmacological activities by in vitro method, narrowing down to $\mathrm{BE}$ due to its least cytotoxicity and good efficacy for the said biological activities.

\section{MATERIALS AND METHODS}

\section{Drugs and chemicals}

Aspirin of Research lab, Mumbai and Indomethacin of Jagsonpal pharmaceuticals, Mumbai were procured; other reagents used were of analytical grade. Alpha-tocopherol of Pellets pharma limited, Hyderabad and metformin from Zydus research center, Ahmadabad were used. Chemicals: 3-(4,5-dimethyl thiazol-2-yl)-5-diphenyl tetrazolium bromide (MTT), fetal bovine serum (FBS), phosphate buffered saline (PBS), Dulbecco's modified eagle's medium (DMEM), endotoxin, dexamethasone and trypsin were obtained from Sigma Aldrich Co, St Louis, USA. EDTA, glucose and antibiotics were procured from Hi-Media laboratories ltd., Mumbai. dimethyl sulfoxide (DMSO) and propanol from E. Merck ltd., Mumbai, India.

\section{Plant material, macroscopic and organoleptic characters}

The present study included five herbal parts. The plants were identified and authenticated by Dr. K. Madhava Chetty, Professor of Botany, Sri Venkateswara University, Tirupathi, Andhra Pradesh. These were collected from Sheshalam forests, India and deposited in the college herbarium with voucher specimen numbers \# T1404-08. For macroscopic and organoleptic characters, visible distinct characters were documented prior to initiation of the actual studies.

\section{Cold extraction and identification of phytochemical constituents}

Cold solvent (80\% ethyl alcohol) maceration method for 7 continuous days was employed. ${ }^{22}$ Standard methods were followed for determination of carbohydrates, alkaloids, glycosides, flavonoids, phenols, saponins, tannins, phytosterols, triterpenoids and fixed oils for each of the five herbs that were evaluated. ${ }^{23}$
Determination of moisture content, extractive value, fluorescence analysis, ash, microbial load, heavy metals and pesticides (Pharmacognostic parameters)

Moisture content or loss on drying, alcohol soluble extractive, water soluble extractive, fluorescence analysis, total ash value, acid insoluble ash, water soluble ash, sulfated ash were determined as per the WHO guidelines. ${ }^{24}$ Investigation for selective microbes like E. coli, Salmonella, Pseudomonas and Staphylococcus aureus and their total microbial count was undertaken using USP method. ${ }^{25}$ The test substances were also analyzed for the presence of heavy metals (Lead and Arsenic) by USP heavy metal methods using ICP-OES (Thermo Fisher, UK).

\section{Evaluation for preliminary in vitro antidiabetic properties:}

\section{Inhibition of glycosylation}

Hemolysate was prepared based on the principle of hypotonic lysis. ${ }^{26,27}$ Vitamin E (alpha tocopherol) with the same strengths of herbals was used as the standard reference drug. The amounts of hydroxymethylfurfural in nanomole released were estimated at $72 \mathrm{~h}$ spectrophotometrically at $540 \mathrm{~nm}$ which correspond to the degree of glycosylation.

\section{Glucose uptake by yeast cells}

For glucose uptake in yeast cells, the yeast cells were prepared according to the method of Yeast cells. ${ }^{28}$ Percent increase in glucose uptake by yeast cells was calculated using previously published protocol. ${ }^{29}$ Amount of glucose was estimated in the supernatant of reaction mixture spectrophotometric ally at $540 \mathrm{~nm}$. Metformin was considered as reference standard drug. All the tests were performed in triplicate.

\section{Evaluation for preliminary immunomodulatory properties:}

\section{Heat-induced hemolysis}

Human erythrocytes suspension was prepared from healthy volunteer blood by centrifuging at $3500 \times g$ for $1 \mathrm{~min}$. Heat and hypotonic induced hemolysis test was performed as described earlier. ${ }^{30}$ The absorbance of the reaction mixture's supernatant was measured spectrophotometric ally at $540 \mathrm{~nm}$. The level of inhibition of hemolysis was calculated as follows:

$\%$ inhibition of hemolysis $(\mathrm{Y})=100 \times(1-\mathrm{A} 2 / \mathrm{A} 1)$

$\mathrm{A} 1=$ Absorption of the control sample.

A2 = Absorption of test sample solution.

\section{Hypotonic induced hemolysis}

For hypotonic solution induced hemolysis, the same procedure as above was repeated except incubation for $1 \mathrm{~h}$ at room temperature and the $\%$ inhibition of hemolysis was calculated as per formula Y.

\section{NBT assay}

Nitroblue terazolium (NBT) assay ${ }^{31}$ was also performed for assessing immunomodulatory properties of selected herbal extracts. Neutrophils were counted for the \% of NBT positive cells containing blue granules/ lumps.

\section{MTT assay for cell viability}

In vitro cytotoxicity studies were performed to select respective concentrations of all five herbs for further studies on cell lines, through MTT assay in RAW cells and L929 cell lines. ${ }^{32}$ The absorbance was measured using a microplate reader at a wavelength of $540 \mathrm{~nm}$. The percentage growth inhibition was calculated using the following formula and con- 
centration of test drug needed to inhibit cell growth by $50 \%\left(\mathrm{CTC}_{50}\right)$ values is generated from the dose-response curves for each cell line.

\section{TNF-a inhibitory activity of extracts}

Tumor necrosis factor (TNF- $\alpha$ ) inhibition was done as per the earlier protocols. ${ }^{[33]}$ The absorbance was measured using a microplate reader at a wavelength of $540 \mathrm{~nm}$ and the percentage cell viability was calculated. The cell viability is direct indication of inhibitory properties of extracts against LPS induced TNF production in RAW cells, dexamethasone was positive control.

\section{Nitric oxide assay}

The nitric oxide (NO) assay was performed as described previously with slight modification. ${ }^{34}$ The standard curve was created by using known concentrations of sodium nitrite, and the absorbance was measured at $540 \mathrm{~nm}$. Macrophages stimulated with LPS and treated with $20 \mu \mathrm{g} / \mathrm{ml}$ L-NMMA (Sigma-Aldrich-98\% purity), a nonspecific NO synthase inhibitor served as positive control. LPS stimulated macrophages and untreated served as negative control.

\section{Infra-red spectroscopy}

Hydro-alcoholic extracts were placed on the sample chamber of FT-IR spectrophotometer and the infra-red spectra were recorded in the range of 4000-400 $\mathrm{cm}^{-1}$ on Nicolet Avatar 330 FTIR spectrometer. Important absorption frequencies appeared in functional group region as well as fingerprint region of the spectra were noted down.

\section{Statistical Analysis}

Data were statistically analyzed by Student's $t$-test and $\mathrm{p}<0.01$ vs. positive control were considered to be significant. For efficacy assessments one way ANOVA followed by Dunnet's t test were used. $\mathrm{IC}_{50}$ values were calculated by non-linear regression using Graph Pad Prism software version 6.01, and all the tests were performed in triplicate.

\section{RESULTS}

\section{Herbal standardization}

All the five herbs belong to five different families with respective macroscopic and organoleptic characters [Table 1]. Phytochemical analysis of the tested herbal extracts had varied constituents [Table 2]. While moisture content was high for Boerhavia erecta; Picrorhiza kurroa has high water and alcohol soluble extractive values [Table 3]. Fluorescence analysis [Table 4] revealed characteristic information for each of the five herbs under ordinary and UV short rays $(254 \mathrm{~nm})$. Picrorhiza kurroa has got the highest total ash and acid insoluble ash (\%) content value, Boerhavia erecta has highest water soluble ash content and Plumeria accuminata has highest sulfated ash (\%) content [Table 5] amongst the tested samples. Alpinia galanga extract has highest bacterial colony forming units (132 X $\left.10^{3} \mathrm{CFU}\right)$, when tested for E.coli, Salmonella, Pseudomonas and Staphylococcus aureus with remaining extracts within USP permitted limits of CFU (results not shown). No fungal colonies were observed for any of the five herbal extracts. Lead and arsenic were the two heavy metals that were tested and Alpinia galanga and Picrorhiza kurroa extracts were found to have significant lead (52.3 ppm) and arsenic (0.5 $\mathrm{ppm}$ ) values respectively (results not shown). Out of all the five herbal extracts tested, Plumeria acuminata and Picrorhiza kurroa were detected

Table 1: Macroscopic \& organoleptic characters of selected medicinal herbs

\begin{tabular}{|c|c|c|c|c|c|}
\hline Item & Boerhavia erecta $\mathrm{L}$. & Plumeria acuminate $\mathrm{R}$. Br. & Alpinia galanga Sw. & $\begin{array}{c}\text { Picrorhiza kurroa Royle } \\
\text { ex Benth. }\end{array}$ & Trapa natans $L$. \\
\hline Leaf & $\begin{array}{l}\text { Fleshy, soft and thick leaves. } \\
\text { Upper portion of the leaf } \\
\text { have tiny hairs }\end{array}$ & $\begin{array}{l}\text { The leaves crowed at the } \\
\text { terminal end of the branch, } \\
\text { oblong in shape, simple and } \\
\text { alternately arranged. }\end{array}$ & $\begin{array}{l}\text { Laves are simple, alternate } \\
\text { and lanceolate. Have wavy } \\
\text { annulations of the leaf } \\
\text { bases. }\end{array}$ & $\begin{array}{c}2-4 \text { inch long, having a } \\
\text { circular shape and sharp } \\
\text { apex }\end{array}$ & $\begin{array}{l}\text { Rosette of floating leaves at } \\
\text { the water's surface; saw-tooth } \\
\text { margins; triangular in shape. }\end{array}$ \\
\hline Flower & $\begin{array}{l}\text { It has determinative } \\
\text { inflorescence and has } \\
\text { multiple flowers on one } \\
\text { branch. }\end{array}$ & $\begin{array}{l}\text { The inflorescence is } \\
\text { cymose, terminal or } \\
\text { axillary, with bracteoles. } \\
\text { flowers are bisexual, } \\
\text { fragrant, the upper portion } \\
\text { whitish, while the inner } \\
\text { lower portion yellow, } 5-6 \mathrm{~cm} \\
\text { long. }\end{array}$ & $\begin{array}{l}\text { Its inflorescence is a short } \\
\text { raceme of white flowers } \\
\text { that are veined and shaded } \\
\text { in dull red. Flowers are } \\
\text { and campanulate. }\end{array}$ & $\begin{array}{l}\text { Flower stalks is } 2-4 \\
\text { inch long that bears } \\
\text { white flowers }\end{array}$ & $\begin{array}{c}\text { Flowers are four-petaled and } \\
\text { white. }\end{array}$ \\
\hline Fruit & $\begin{array}{l}\text { They are 5-ribbed and } \\
\text { glabrous. The ribs have a } \\
\text { wrinkly texture and have } \\
\text { needle- like crystals. The } \\
\text { fruits are sticky. }\end{array}$ & $\begin{array}{l}\text { The fruits are linear oblong } \\
\text { or ellipsoid follicles. These } \\
\text { are brownish black in } \\
\text { colour, seeds are oblong }\end{array}$ & Fruit is orange red & $\begin{array}{c}\text { Fruit is } 1 / 2 \text { inch long and } \\
\text { is oval in shape }\end{array}$ & $\begin{array}{l}\text { Fruit is a nut with four } \\
1 / 2 \text {-inch, barbed spines }\end{array}$ \\
\hline Root & Stout root stock. & $\begin{array}{l}\text { Root bark is violent and } \\
\text { cathartic. }\end{array}$ & $\begin{array}{l}\text { Bushy roots but are } \\
\text { overshadowed by } \\
\text { the rhizome, a stem } \\
\text { modification. }\end{array}$ & Short roots with aroma & $\begin{array}{l}\text { Very fine roots modified to } \\
\text { suit the floating habitat of } \\
\text { the plant. }\end{array}$ \\
\hline Part used & Root \& stem & Leaf & Rhizome & Whole plant & Fruit \\
\hline Appearance & Powder & Powder & Powder & Powder & Powder \\
\hline Colour & Orange & Light brown & Brown & Dark brown & Colourless \\
\hline Odour & Odourless & Odourless & Odourless & Sweet odour & Vinegar odour \\
\hline Taste & No characteristic & No characteristic & No characteristic & No characteristic & No characteristic \\
\hline
\end{tabular}


with respective 2,4-DDE and 2,4-DDT in the organo-chlorine pesticide contents estimation. None of the extracts were found to have organophosphorus pesticide contents. Cytotoxicity of tested drugs against RAW and L929 cell lines indicate Boerhavia erecta as least toxic at more than $1000 \mu \mathrm{g} / \mathrm{mL}$ [Table 6].

\section{Antidiabetic and immunomodulatory study results:}

Towards antidiabetic studies [Figure 1], inhibition of glycosylation of hemoglobin and glucose uptake tests, Boerhavia erecta, Alpinia galanga and Picrorhiza kurroa showed significant $(\mathrm{p}<0.01)$ inhibition from their respective positive controls. In immunomodulatory studies, Alpinia galanga and Picrorhiza kurroa extracts showed significant $(\mathrm{p}<0.01)$ inhibition of hemolysis, both by heat and hypotonic induced methods, when compared with Aspirin, the positive control in the test [Figure 2]. Statistically significant difference $(\mathrm{p}<0.01)$ was obtained for Boerhavia erecta and Alpinia galanga from positive control in NBT test [Figure 3]. Boer- havia erecta demonstrated maximum inhibition of TNF $\alpha$ and Nitric oxide at $1000 \mu \mathrm{g} / \mathrm{mL}$ in RAW cells [Figure 4a], while Alpinia galanga and Picrorhiza kurroa exhibited better activity than the remaining two herbs, at various strengths though, thereby indicating these herbs as potential sources for immunomodulatory activity.

\section{Infra-red spectral analysis}

Infra-red spectra of the hydro-alcoholic extracts were found to have various functional groups responsible for biological activities. Though IR spectral analysis of all extracts was performed, spectral data of chloroform fraction of $80 \%$ hydro-alcoholic extract of $\mathrm{BE}$ alone is emphasized here, reported for the first time, which showed absorption bands at 2951, 2849 and 1473 confirming the presence of C-H bonds in the molecule, and is reported for the first time [Figure 5].

Table 2: Preliminary phytochemical analysis of selected medicinal herbs

\begin{tabular}{|c|c|c|c|c|c|}
\hline Test & $\begin{array}{l}\text { Boerhavia } \\
\text { erecta L. }\end{array}$ & $\begin{array}{c}\text { Plumeria acuminate } \\
\text { R. Br. }\end{array}$ & Alpinia galanga Sw. & $\begin{array}{c}\text { Picrorhiza kurroa Royle ex } \\
\text { Benth. }\end{array}$ & Trapa natans L. \\
\hline \multicolumn{6}{|l|}{ Test for carbohydrates } \\
\hline a. Molisch's test & - & - & - & - & - \\
\hline \multicolumn{6}{|l|}{ Test for Glycosides } \\
\hline a. Keller-Killiani test & - & - & + & - & + \\
\hline \multicolumn{6}{|l|}{ Test for Saponins } \\
\hline a. Foam test & - & + & - & - & - \\
\hline \multicolumn{6}{|l|}{ Test for Alkaloids } \\
\hline a. Dragendrodroff's test & - & + & + & + & + \\
\hline \multicolumn{6}{|l|}{ Test for Flavonoids } \\
\hline Alkaline reagent test & + & + & + & + & + \\
\hline \multicolumn{6}{|l|}{ Test for Phenolics and Tannins } \\
\hline a. Ferric chloride test & + & + & - & + & + \\
\hline b. Test for Tannins & - & + & - & - & - \\
\hline \multicolumn{6}{|l|}{ Test for Phytosterols and Triterpenoids } \\
\hline a. Leiberman-Bucharat test & - & - & - & - & - \\
\hline b. Salkowaski test & - & + & - & - & - \\
\hline \multicolumn{6}{|l|}{ Test for fixed oils and fats } \\
\hline a. Oily spot test & + & - & - & - & - \\
\hline
\end{tabular}

(-) absent (+) present

Table 3: Moisture, water \& alcohol extractive values of selected hydroalcoholic herbs

\begin{tabular}{cccc}
\hline Test sample & $\begin{array}{c}\text { Moisture content } \\
(\%)\end{array}$ & $\begin{array}{c}\text { ASE } \\
(\%)\end{array}$ & $\begin{array}{c}\text { WSE } \\
(\%)\end{array}$ \\
\hline Boerhavia erecta L. (root \& stem) & 7.2 & 9 & 3 \\
Plumeria acuminate R. Br.(leaf) & 5.2 & 15 & 36 \\
Alpinia galanga Sw. (rhizome) & 5.6 & 10 & 18 \\
Picrorhiza kurroa Royle ex Benth. & 5.8 & 22 & 40 \\
$\quad$ (whole plant) & & & \\
Trapa natans L. (fruit) & 2.4 & 4 & 14 \\
\hline
\end{tabular}

ASE: Alcohol soluble extract, WSE: Water soluble extract

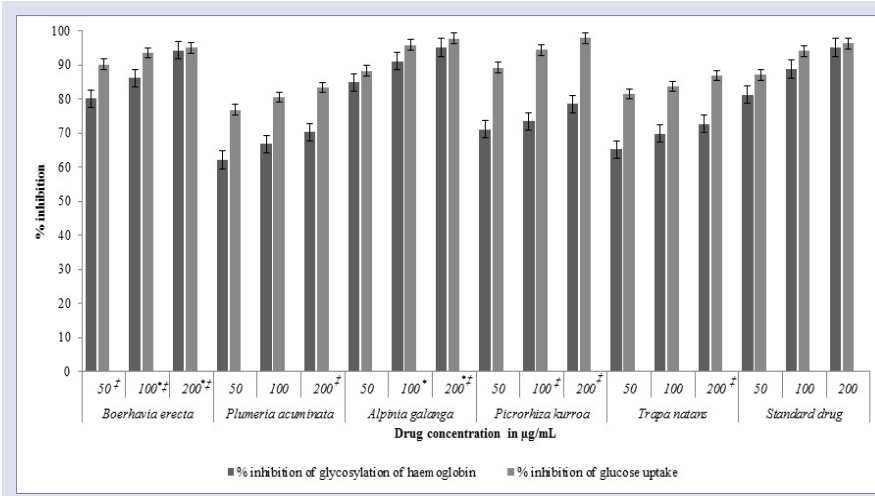

Figure 1: Effect of hydro-alcoholic extracts of five test herbs on percent inhibition of glycosylation of hemoglobin and glucose uptake. Values expressed as mean \pm S.D. $n$ $=3 .{ }^{*} p<0.01$ Vs Vitamin $E, \neq p<0.01$ Vs Metformin 


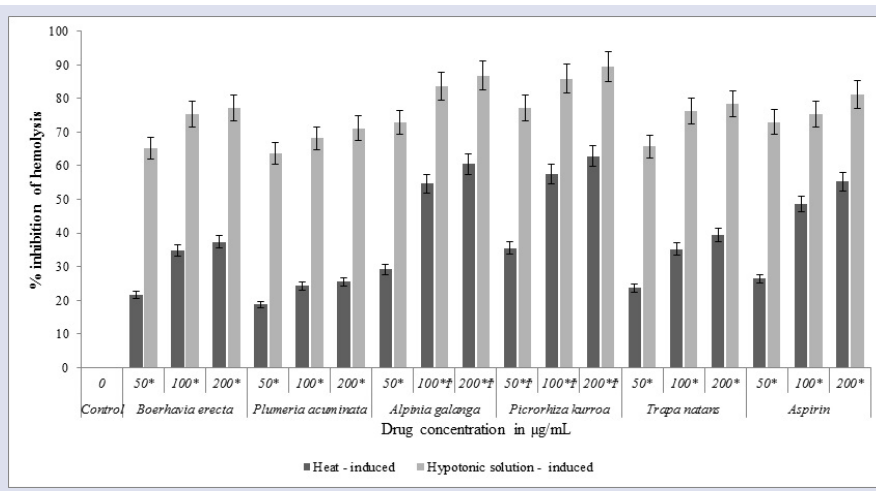

Figure 2: Effect of hydro-alcoholic extracts of five test herbs on heat-induced and hypotonic solution induced hemolysis of erythrocyte membrane Caption: Values are mean \pm S.D., $n=3$; ${ }^{*} p<0.001$ Vs control, ? $p<0.01$ Vs Aspirin for respective concentrations

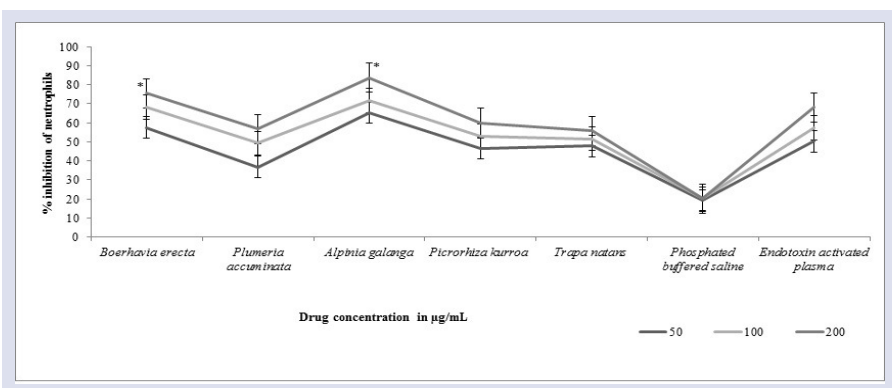

Figure 3: Percent of reduced neutrophils after treatment with various concentrations of hydro-alcoholic extracts of five test herbs, determined by nitroblue tetrazolium test Caption: Values expressed as mean \pm S.D. Phosphated buffer saline is normal control and endotoxin activated plasma is positive control. *Statistically significant difference $(p<0.01)$ was obtained for Boerhavia erecta and Alpinia galanga from positive control by one way ANOVA followed by Dunnet's t test, $\mathrm{n}=3$

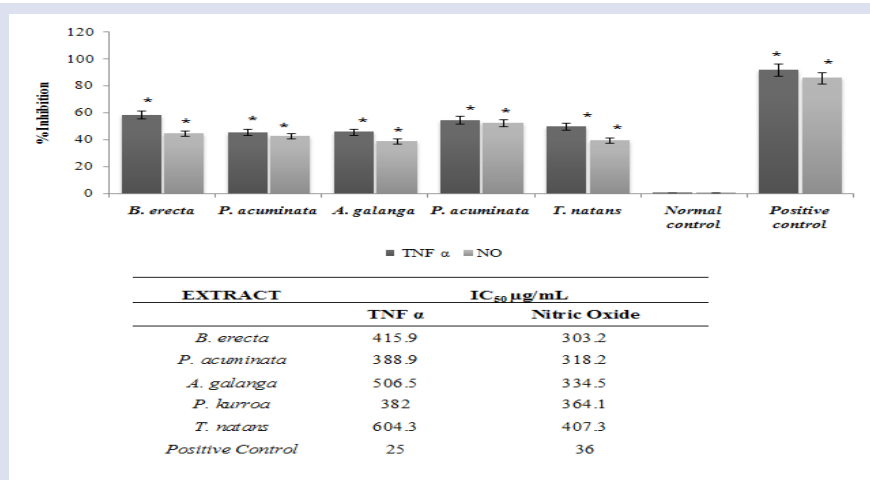

Figure 4: Immunomodulatory activity of standardized herbal extracts by in vitro methods 4a: The percent inhibition against LPS induced TNF-a and NO production in RAW cells ${ }^{*} \mathrm{p}<0.01$ 4b: $: \mathrm{C}_{50}$

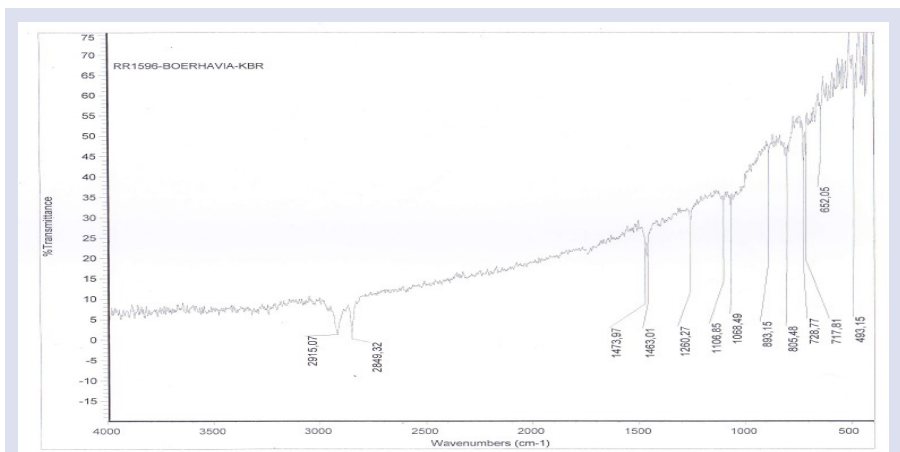

Figure 5: FT-IR spectrum of chloroform fraction of Boerhavia erecta hydro-alcoholic extract

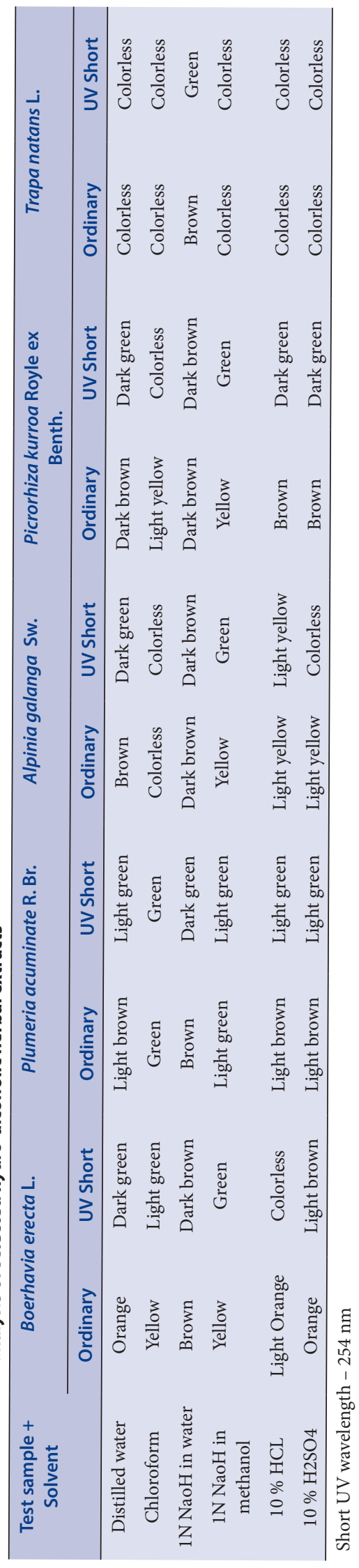


Table 5: Ash values of selected medicinal herbs

\begin{tabular}{ccccc}
\hline Sample & Total Ash (\%) & Acid insoluble Ash (\%) & Water soluble Ash (\%) & Sulfated Ash (\%) \\
\hline Boerhavia erecta L. (root \& stem) & 4.66 & 0.63 & 3.66 & 7.7 \\
Plumeria acuminate R. Br.(leaf) & 10.0 & 2.0 & 2.66 & 18.5 \\
Alpinia galanga Sw. (rhizome) & 5.26 & 1.73 & 1.33 & 6.33 \\
Picrorhiza kurroa Royle ex Benth.(whole plant) & 10.33 & 6.66 & 1.00 & 8.3 \\
Trapa natans L. (fruit) & 2.66 & 0.33 & 1.33 & 3.5 \\
\hline
\end{tabular}

Table 6: Cytotoxic properties of test drugs against RAW and L929 cell lines

\begin{tabular}{|c|c|c|c|c|c|}
\hline \multirow[b]{2}{*}{ Test sample } & \multirow[b]{2}{*}{ Test Conc. ( $\mu \mathrm{g} / \mathrm{ml})$} & \multicolumn{2}{|c|}{ Cytotoxicity against RAW cell line } & \multicolumn{2}{|c|}{ Cytotoxicity against L929 cell line } \\
\hline & & $\%$ Cytotoxicity & $\mathrm{CTC}_{50}(\mu \mathrm{g} / \mathrm{mL})$ & $\%$ Cytotoxicity & $\mathrm{CTC}_{50}(\mu \mathrm{g} / \mathrm{mL})$ \\
\hline Untreated control & 0 & 0 & - & 0 & - \\
\hline \multirow[t]{5}{*}{ Boerhavia erecta $\mathrm{L}$. } & 1000 & $15.79 \pm 0.8$ & & $25.28 \pm 0.6$ & \\
\hline & 500 & $14.42 \pm 1.8$ & $>1000 \pm 0.00$ & $21.24 \pm 0.4$ & $>1000 \pm 0.00$ \\
\hline & 250 & $7.53 \pm 1.0$ & & $16.24 \pm 0.2$ & \\
\hline & 125 & $2.76 \pm 0.4$ & & $13.32 \pm 0.4$ & \\
\hline & 62.5 & $1.07 \pm 0.7$ & & $8.69 \pm 0.6$ & \\
\hline \multirow[t]{5}{*}{ Plumeria acuminate R. Br. } & 1000 & $51.40 \pm 0.9$ & & $52.36 \pm 1.1$ & \\
\hline & 500 & $30.71 \pm 2.6$ & $960.00 \pm 1.3$ & $38.58 \pm 1.9$ & $913.33 \pm 1.0$ \\
\hline & 250 & $11.28 \pm 1.3$ & & $18.96 \pm 0.3$ & \\
\hline & 125 & $2.76 \pm 0.4$ & & $8.98 \pm 0.7$ & \\
\hline & 62.5 & $1.07 \pm 0.7$ & & $6.25 \pm 0.5$ & \\
\hline \multirow[t]{5}{*}{ Alpinia galanga Sw. } & 1000 & $54.13 \pm 1.9$ & & $55.83 \pm 0.8$ & \\
\hline & 500 & $51.12 \pm 1.7$ & $226.67 \pm 2.7$ & $53.28 \pm 0.5$ & $233.33 \pm 1.1$ \\
\hline & 250 & $51.81 \pm 0.7$ & & $52.27 \pm 0.4$ & \\
\hline & 125 & $36.43 \pm 3.6$ & & $36.84 \pm 2.8$ & \\
\hline & 62.5 & $18.40 \pm 3.8$ & & $16.26 \pm 0.5$ & \\
\hline \multirow[t]{5}{*}{ Picrorhiza kurroa Royle ex Benth. } & 1000 & $74.60 \pm 0.8$ & & $68.86 \pm 0.6$ & \\
\hline & 500 & $64.86 \pm 0.9$ & $103.33 \pm 1.0$ & $65.94 \pm 0.5$ & $63.33 \pm 0.5$ \\
\hline & 250 & $60.40 \pm 0.8$ & & $62.04 \pm 0.3$ & \\
\hline & 125 & $54.32 \pm 1.7$ & & $58.94 \pm 0.7$ & \\
\hline & 62.5 & $39.24 \pm 3.3$ & & $48.85 \pm 0.3$ & \\
\hline \multirow[t]{5}{*}{ Trapa natans L. } & 1000 & $74.71 \pm 0.5$ & & $75.22 \pm 0.4$ & \\
\hline & 500 & $72.28 \pm 0.4$ & $163.33 \pm 0.9$ & $72.48 \pm 0.5$ & $150.00 \pm 0.6$ \\
\hline & 250 & $60.59 \pm 1.0$ & & $61.97 \pm 0.9$ & \\
\hline & 125 & $44.66 \pm 1.7$ & & $47.73 \pm 0.4$ & \\
\hline & 62.5 & $38.70 \pm 0.5$ & & $39.78 \pm 0.8$ & \\
\hline
\end{tabular}

No statistical significance in cytotoxicity when compared with untreated control

\section{DISCUSSION}

Due to lack of appropriate parameters for the standardization of herbal preparation and several instances of substandard herbs, adulterated herbs have come into existence. Hence, standardization of herbals is mandatory. ${ }^{35,36,37}$ Therefore, herbal standardization techniques were employed in our study prior to their pharmacological evaluations. Macroscopic characters of various parts of these five herbs were different from each other including their organoleptic properties. Total ash and acid insoluble ash are important indices of quality as well as purity of herbal medicine. Qualitative or quantitative determination of mineral elements present in plants is important because the concentration and type of minerals present must often be stipulated on the label of a food or drug. The fluorescence color is specific for each compound. A non-fluorescent compound may fluoresce if mixed with impurities that are fluorescent. ${ }^{38}$ Simple pharmacognostic techniques used in standardization of plant material include its morphological features, physico-chemical constant, fluorescence analysis and preliminary photochemical analysis. ${ }^{39}$ Hence, all the aforesaid quality control aspects were thoroughly investigated prior to in vitro efficacy studies in the present work.

Though herbal medicines often combine different botanicals, only a part of them exhibit favorable pharmacokinetics with greater potential 
to exert the required biological effect. ${ }^{40}$ To preserve heat sensitive molecules, if any, cold extraction procedure was followed. Herbal medicines are not subjected to the same safety regulatory standards as orthodox drugs which raises concern on their safety and implications for their use as medicines. Toxicity testing can reveal some of the risks that may be associated with use of herbs; therefore potential harmful effects could be avoided when used as medicine. The selected herbs were also tested for their in vitro cytotoxic properties [Table 6] prior proceeding to the targeted efficacy tests. All the herbal extracts were assessed for their solubility in DMSO and found that the extracts were sparingly soluble from 62.5 to $1000 \mu \mathrm{g} / \mathrm{mL}$. Hence these concentrations were selected for cell viability tests. All five herb extracts showed different CTC $_{50}$ values both in RAW and L929 cell lines and therefore for comparing their relative antidiabetic and immuno-modulatory activities three similar dose or concentrations (50, 100 and $200 \mu \mathrm{g} / \mathrm{mL}$ ) was considered, except for TNF - $a$ and Nitric oxide inhibition studies. It should be noted that all these three doses were selected with reference to Picorrhiza kurroa which showed highest $\mathrm{CTC}_{50}$ at $103 \mu \mathrm{g} / \mathrm{mL}$ (the other extracts are far less cytotoxic at this concentration). Therefore, one lower dose $(50 \mu \mathrm{g} / \mathrm{mL})$, one medium $(100 \mu \mathrm{g} / \mathrm{mL})$ and one high dose $(200 \mu \mathrm{g} / \mathrm{mL})$ of $P$. kurroa were selected and same concentration of other herb extracts were used for evaluating their relative efficacy.

In the efficacy studies, herbal extracts displayed antidiabetic activity by inhibition of hemoglobin glycosylation at different physiological concentrations of the glucose over $72 \mathrm{~h}$ time period, indicating that the herbal extracts decrease the formation of the glucose- hemoglobin complex and thus increasing the amount of free hemoglobin. Boerhavia erecta, Alpinia galanga and Picrorhiza kurroa showed significant inhibition $(\mathrm{p}<0.01)$ from respective standard controls of both glycosylation of hemoglobin and glucose uptake tests. With high concentration of drug, formation of glucose-hemoglobin decreases and free hemoglobin increases, demonstrating inhibition of glycosylated hemoglobin. Type 1 diabetes is an autoimmune disorder and glycosylation of hemoglobin manifests in the advanced stage of diabetes. Reduced glucose uptake by peripheral tissues in turn leads to a reduced rate of glucose metabolism in insulin dependent diabetes metabolism (IDDM), therefore, both these were considered as in vitro autoimmune diabetes model.

Immunomodulatory response was exhibited by stabilization of lysosomal membrane and thereby limiting the release of lysosomal constituents of activated neutrophil such as bactericidal enzymes and proteases. The non-steroidal drugs act either by inhibiting these lysosomal enzymes or by stabilizing the lysosomal membrane. All herbal extracts under study exhibited statistically significant $(\mathrm{p}<0.01$ to $\mathrm{p}<0.001)$ membrane stabilization effect by inhibiting both hypotonicity and heat induced lysis of erythrocytes when compared with the standard drug acetylsalicylic acid (aspirin) at three different strengths. Furthermore, the herbal extracts significantly increased the intracellular reduction of NBT dye to formazan (deep blue compound) by the neutrophils, confirming the intracellular killing property of phagocytosing neutrophils. As a part of host defense, upon inflammatory stimuli, such as lipopolysaccharide (LPS), macrophages trigger signals for the production of diverse inflammatory mediators, such as TNF- $a$ and NO. Only three safe values were selected for efficacy studies considering higher herbal $\mathrm{CTC}_{50}$ concentrations. However, all 5 possible concentrations were considered for calculating $\mathrm{IC}_{50}$ values [Figure $4 \mathrm{~b}$ ]. $\mathrm{PK}$ and $\mathrm{BE}$ demonstrated better $\mathrm{IC}_{50}$ values but none of them were close to positive control. In the 96 well plate, the number of cells seeded was observed. Only those cells which survived were tested for their inhibitory properties with respect to TNF- $\alpha$ and NO.

Out of 5 selected herbs, it was found that only two herbs had safe (free of heavy metals) and free of cytotoxic potential when tested at similar concentrations. The numbers of viable activated macrophages were not significantly altered by the plant extracts as determined by MTT assays, thereby indicating that the inhibition of TNF $-\alpha$ and NO synthesis by the plant extracts was not due to cytotoxic effects. Of the tested herbs, B. erecta showed highest (58.1\%) inhibition of TNF- $\alpha$ and NO (45.6\%) production in RAW cells at $1000 \mu \mathrm{g} / \mathrm{mL}$. As described in $\mathrm{WHO},{ }^{41}$ for standardization and quality control of herbs, all major herbal standardization procedures were used, not completely though, forming a limitation of the present study. Identification and analysis of functional groups helps to evaluate their structure- activity relationships. In the present work, FT-IR spectral analysis of chloroform fraction of hydro-alcoholic extract of BE showed the presence of hydrogen bonded - OH functional group. Our results indicate that root and stem extracts of $B$. erecta contain various biologically active functional groups, viz. alcoholic, ester, aldehyde etc., and hence we can confirm that the plant possesses bioactive phytochemicals.

In conclusion, besides reports on preliminary in vivo anti-inflammatory activities for the five short listed herbal extracts, no other literature is available for their antidiabetic and immunomodulatory activities on the herbal parts that are very commonly being used as folk medicine by few tribes of south India. From the present study it is concluded that the pharmacognostic characteristics and phytochemical parameters together might be useful to supplement information about their identification parameters. Furthermore, different parts of hydro-alcoholic (80\%) extracts of all five herbs have shown antidiabetic and immunomodulatory activities when compared to their respective positive controls. However, $B$. erecta was found to possess greater extent of said pharmacological activities at far less concentration to their $\mathrm{IC}_{50}$ values due to the presence of bioactive molecules, perhaps flavonoids or phenolic groups. More ex vivo and in vivo autoimmune studies on the responsible molecule isolated from the active fractions are further warranted to confirm our results.

\section{ACKNOWLEDGEMENT}

We would like to extend our heartfelt thanks to the management of VIT University, Vellore and Radiant Research Private Limited, Bangalore for their support.

\section{CONFLICT OF INTEREST}

The authors report no competing interests.

\section{ABBREVIATIONS USED}

AG: Alpinia galanga; ANOVA: Analysis of variance; BE: Boerhavia erecta; CFU: Colony-forming units; CTC: Cytotoxic concentration; FTIR: Fourier transform infrared spectroscopy; IC: Inhibitory concentration; ICP-OES: Inductively coupled plasma: optical emission spectrometry; LPS: Lipopolysaccharides; NO: Nitric oxide; PA: Plumeria acuminate; PK: Picrorhiza kurroa; RA: Rheumatoid Arthritis; T1D: Type 1 Diabetes; TN: Trapa natans; TNF: Tumor necrosis factor; USP: United States Pharmacopeia.

\section{REFERENCES}

1. Tirtha SSS. Overview of Ayurveda In the Ayurveda Encyclopedia: Natural secrets to healing, prevention and longevity. New Delhi: Amrit Kaur Khalsa and Rob Paon Satyaguru Publications; 1998.

2. Tyler VE. Phytomedicine: Back to the future. J Nat Prod. 1999;62:1589-92 https://doi.org/10.1021/np9904049; PMid:10579884.

3. Classen DC, Pestotnik SL, Evans RS. Adverse drug events in hospitalized patients-Excess length of stay, extra costs, and attributable mortality. JAMA. 1997;277(4):301-6. https://doi.org/10.1001/jama.277.4.301 : https://doi. org/10.1001/jama.1997.03540280039031; PMid:9002492.

4. Sheetal V and Singh SP. Current and future status of herbal medicines. Veterinary World. 2008;1(11):347-50.

5. Rakhi M, Shuaib Md, Shravan S. A review on herbal antidiabetic drugs. JAPS 2011;01:235-7. 
6. Kushagra N, Mukesh S, Abhishek A. General awareness on allopathic, ayurvedic and homeopathic system of medicine in Chhattisgarh. Int J Pharm Pharm Sci. $2011 ;(3): 159-62$

7. Claudia R, Günther B, Helmut K, Prostaglandin E2 and tumor necrosis factor alpha cooperate to activate human dendritic Cells: Synergistic activation of interleukin 12 production. J Exp Med. 1997;186(9):1603-8. https://doi.org/10.1084/ jem.186.9.1603

8. Sanjoy KP and Yogeshwer S. Current status and the future of herbal medicine. Asian Pacific J Cancer Pre. 2003;4:281-8.

9. Daniel TA and Lars K. Tumor necrosis factor antagonist mechanisms of action: A comprehensive review. Pharmacol Ther. 2008;117(2):244-79. https://doi. org/10.1016/j.pharmthera.2007.10.001; PMid:18155297.

10. Pawel K. Regulation of immune responses. J Immunol. 2012;188:21-8. https:// doi.org/10.4049/jimmunol.1101029 ; PMid:22187483 PMCid:PMC3249979.

11. Cheung F. TCM: Made in China. Nature. 2011;480:S82-3. https://doi. org/10.1038/480S82a ; PMid:22190085.

12. Rajeswari P. and Krishnakumari S. Boerhavia erecta-A potential source for phytochemicals and antioxidants. J Pharm Sci and Res. 2010;2:728-33.

13. Singh PK, Baxi D, Doshi A. Antihyperglycaemic and renoprotective effect of Boerhaavia diffusa $\mathrm{L}$. in experimental diabetic rats. J Complement Integr Med. 2011;8(1):140-8. https://doi.org/10.2202/1553-3840.1533; PMid:22754925.

14. Pandey R, Maurya R, Singh G. Immunosuppressive properties of flavonoids isolated from Boerhaavia diffusa Linn. Int Immunopharmacol. 2005;5(3):541-53. https://doi.org/10.1016/j.intimp.2004.11.001; PMid:15683850.

15. Rastogi RP, Mehrotra BN. Compendium of Indian medicinal plants, CDRI, Lucknow: NISCAIR; 1969;320-2.

16. Mahajan RT and Badgujar SB. Phytochemical investigation of some Laticiferous plants belonging to Khandesh region of Maharashtra. Ethnobotanical Leaflets. 2008;12:1145-52.

17. Unisa A and Parveen TD. Anti-inflammatory and acute toxicity studies of the extract from the rhizomes of Alpinia galanga Wild. Der Pharmacia Sinica. 2011;2:361-7.

18. Bendjeddou D, Lalaoui. K, Satta D. Immunostimulating activity of the hot water-soluble polysaccharide extracts of Anacyclus pyrethrum, Alpinia galanga and Citrullus colocynthis. J Ethnopharmacol. 2003:88(2):155-60. https://doi. org/10.1016/S0378-8741(03)00226-5.

19. Atal CK, Sharma ML, Kaul A. Immunomodulating agents of plant origin. I: preliminary screening. J Ethnopharmacol. 1986;18(2):133-41. https://doi. org/10.1016/0378-8741(86)90025-5

20. Akhtar MS, Khan MA, Malik MT. Hypoglycaemic activity of Alpinia galanga rhizome and its extracts in rabbits. Fitoterapia. 2002;73(7):623-8. https://doi. org/10.1016/S0367-326X(02)00235-6.

21. Subedi BP. Plant profile: Kutki (Picrorhiza scrophulariiflora). Khathmandu: Himalayan Bioresources; 2000

22. Harborne JB. Phytochemical Methods - A Guide to modern techniques of plant analysis. London: Chapman and Hall; 1998

23. Trease GE and Evans WC. Textbook of Pharmacognosy, London: Bailliere Tin- dall; 1989

24. Anonymous, Quality Control Methods for Medicinal Plant Materials. World Health Organization. Geneva: 1998;25-8.

25. Anonymous, The Official Compendia of Standards. Rockville, Maryland, The United States Pharmacopeial Convention: USP. 34/NF 29;2011.

26. Umapathy E, Ndebia EJ, Meme A. An experimental evaluation of Albuca setosa aqueous extract on membrane stabilzation, protein denaturation and white blood cell migration during acute inflammation. J Med Plants Res. 2010;4(9):789-95.

27. Adisa RA, Oke J, Olomu SA. Inhibition of human hemoglobin glycosylation by flavonoid containing leaf extracts of C. ferrugunea. J Cam Acad Sc. 2004;4(3):351-9

28. Megha G, Chaudhari BB, Joshi KN. In vitro antimicrobial activity of stem bark of Bauhinia purpurea. IJBSP. 2013;4:29-35.

29. Gupta D, Kondongala S, Chandrashekher. In vitro antidiabetic activity of pentacyclic tritrprnoida and fatty acid ester from Bauhinia purpurea. Int $\mathrm{J}$ of Pharmacology and Pharm Technology. 2013;2:2277-86.

30. Shinde UA, Phadke AS, Nari AM, Membrane stabilzation activity - a posible mechanism of action for the anti-inflammatory activity of Cedrus deodora wood oil. Fitoterapia. 1999;70:251-7. https://doi.org/10.1016/S0367-326X(99)00030-1.

31. Wilkinson PC. Neutrophil leucocytes function test. Techniques in clinical immunology. 3rd ed. London, UK: Blackwell Scientific; 1981;273-93.

32. Pavan KB, Ashok G, Mohammed I. In vitro cytotoxicity of caralluma species by MTT and Tryptan blue dye exclusion. Asian J Pharm Clin Res. 2014;7(2):17-9.

33. Varma R S, Ashok G, Vidyashankar S. Anti-inflammatory properties of Septilin in lipopolysaccharide activated in monocytes and macrophage. Immunopharmaco Immunotoxicol. 2011;33(1):55-63. https://doi.org/10.3109/08923971003739236 - PMid:20384571.

34. Yoon WJ, Kim SS, Oh TH. Abies koreana essential oil inhibits drug-resistant skin pathogen growth and LPS-induced inflammatory effects of murine macrophage. Lipids. 2009;44(5):471-6. https://doi.org/10.1007/s11745-009-3297-3; PMid:19350303.

35. Chaudhury RR. Herbal Medicine for Human Health, World Health Organization Geneva. New Delhi: CBS publishers and distributors Itd; 1999.

36. Yan XJ, Zhou JJ, Xie GR. Traditional Chinese medicines: Molecular Structures, Natural Sources and Applications. London: Aldershot, Ashgate; 1999.

37. Raina MK. Quality control of herbal and herbo-mineral formulations. IJNPR 2003; $19: 11-5$

38. Tara Chand, Bhandari A, Kumawat BK. Phytochemical investigation of seed of Cucumis callosus (Rottl.) Cogn., RJPBCS. 2012;3(2):570-6.

39. Kumar M, Prodyut M, Sudarshana B. Physico-chemical evaluation, preliminary phytochemical investigation, fluorescence and TLC analysis of leaves of the plant Lasiaspinosa (lour) thwaites. Int J Pharm Pharm Sci. 2013;5(2):306-10.

40. Jain A, Bhatiwal S, Chaudhary J. Trapa natans (water chestnut: An overview) IRJP. 2012:3:31-3.

41. Anonymous. Macroscopic and Microscopic Examination: Quality Control Methods for Medicinal Plant Materials. WHO Geneva; 1998. p.1-115.

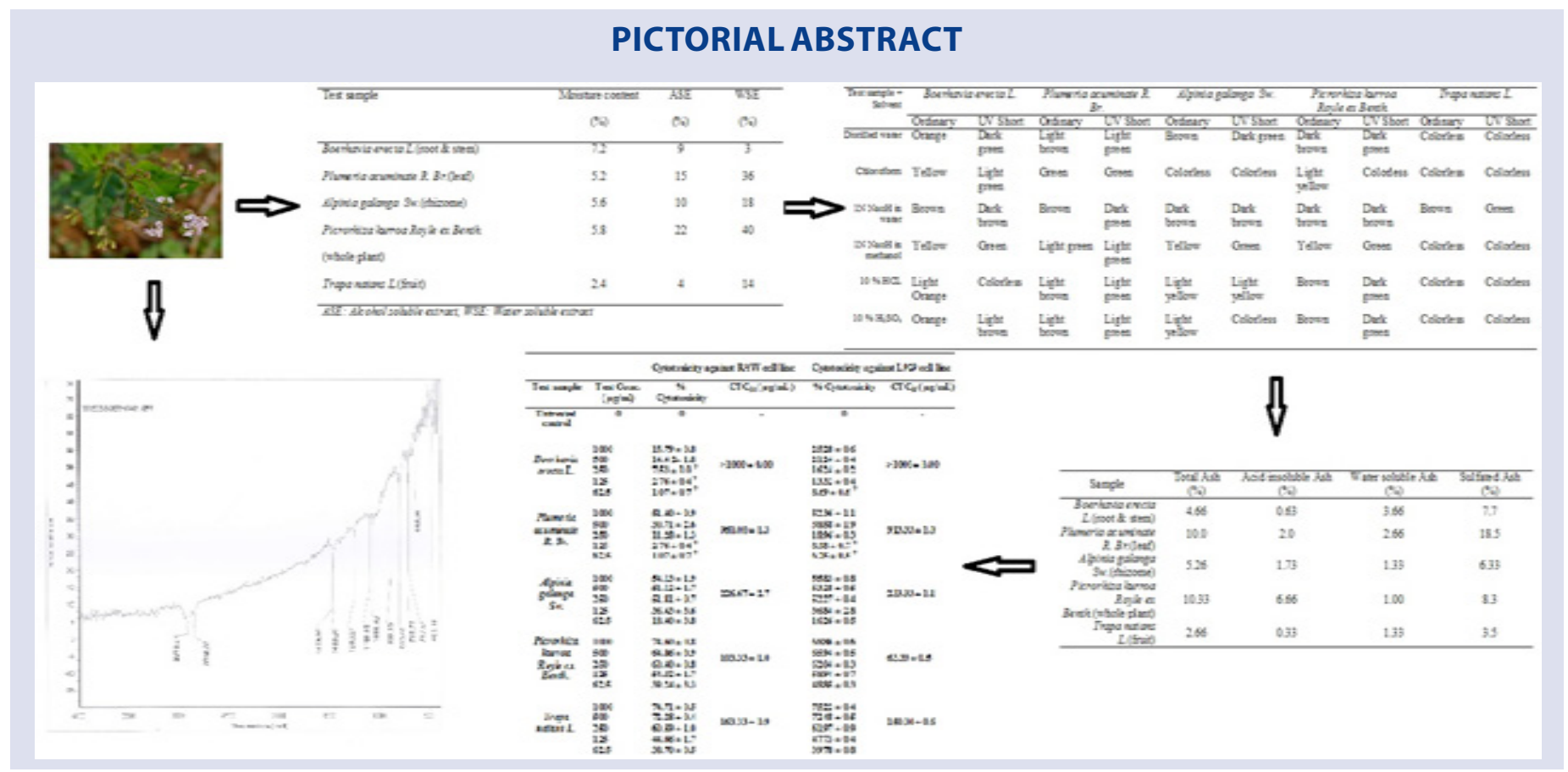




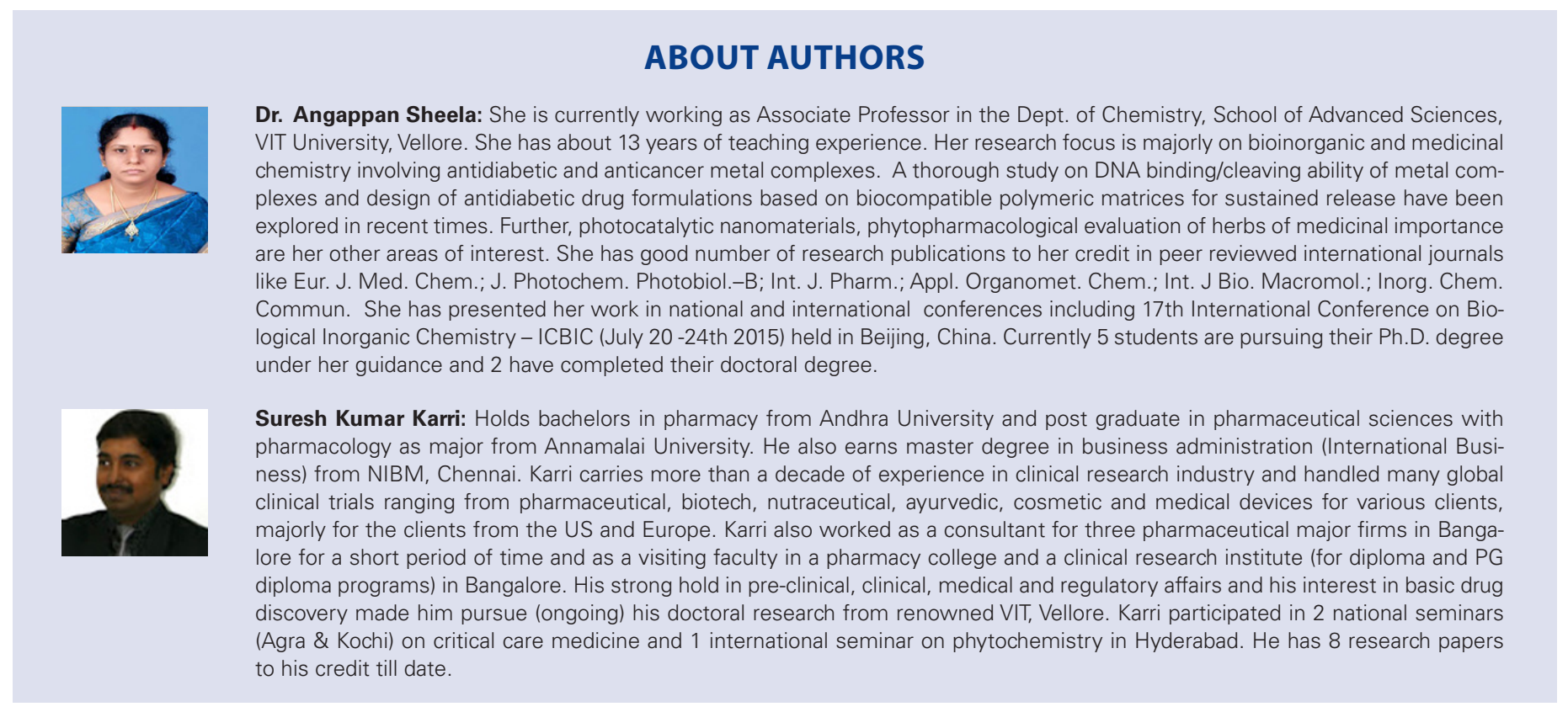

Cite this Article: Karri SK, Sheela A. Comparative in vitro Antidiabetic and Immunomodulatory Evaluation of Standardized Five Select Medicinal Herbs and Spectral Analysis of Boerhavia erecta L. (Nyctaginaceae). Pharmacogn J. 2017;9(3):336-44. 